University of Pennsylvania Carey Law School

Penn Law: Legal Scholarship Repository

Faculty Scholarship at Penn Law

6-9-2009

\title{
The Transparency President? The Obama Administration and Open Government
}

\author{
Cary Coglianese \\ University of Pennsylvania Carey Law School
}

Follow this and additional works at: https://scholarship.law.upenn.edu/faculty_scholarship

Part of the American Politics Commons, Law and Politics Commons, Law and Society Commons, Public Administration Commons, Public Law and Legal Theory Commons, and the Public Policy Commons

\section{Repository Citation}

Coglianese, Cary, "The Transparency President? The Obama Administration and Open Government" (2009). Faculty Scholarship at Penn Law. 273.

https://scholarship.law.upenn.edu/faculty_scholarship/273

This Article is brought to you for free and open access by Penn Law: Legal Scholarship Repository. It has been accepted for inclusion in Faculty Scholarship at Penn Law by an authorized administrator of Penn Law: Legal Scholarship Repository. For more information, please contact PennlawIR@law.upenn.edu. 


\title{
The Transparency President? The Obama Administration and Open Government
}

\author{
Cary Coglianese \\ Deputy Dean for Academic Affairs \\ Edward B. Shils Professor of Law \\ Professor of Political Science \\ Director, Penn Program on Regulation \\ University of Pennsylvania
}

President Obama has trumpeted transparency as a major part of his reform agenda, promising an "unprecedented" degree of governmental openness and overseeing a variety of open government reforms, from changes in Freedom of Information Act policies to the creation of new websites like Recovery.Gov. Although transparency is politically popular, and the Obama Administration benefits in the short run by contrasting itself with the Bush Administration's reputation for secrecy, in the long run President Obama's rhetoric on openness in government may backfire politically. Too much emphasis on making government a fishbowl will only raise expectations about an unattainable or undesirable level of openness. Transparency has clear benefits but it also has its costs, as when, for example, the prospect of disclosure dampens internal deliberation and self-criticism by government officials. The real choice for government, then, is how much transparency, and what type, to offer over different processes. The Obama Administration has already found itself needing to make tradeoffs and place limits on transparency, and it is likely to continue to do so in the years to come. Yet members of the public, and certainly open-government activists, are unlikely to appreciate the need for making such tradeoffs, generating disappointment among the administration's supporters and charges of hypocrisy by its opponents. It remains unclear whether Barack Obama will ultimately earn the mantle of the "transparency president" - or whether the unrealistic hopes for openness in government he has raised will, when unfulfilled, only serve to reinforce public cynicism about government. 


\section{The Transparency President? The Obama Administration and Open Government

\author{
Cary Coglianese \\ University of Pennsylvania
}

President George W. Bush left his successor more than just two major military engagements and a massive economic crisis. He also left behind a wake of public cynicism and concern about the legitimacy of the federal government in the United States. To many observers, the Bush Administration operated too much in the dark, begetting a general mistrust of the administration's motives and actions. This mistrust extended beyond the administration's handling of its unpopular military and foreign affairs, a domain where a high level of secrecy is certainly customary, if not expected. Complaints about the Bush Administration's secrecy also arose in the sphere of domestic policy, from the beginning of Bush's first term through his entire eight years in office.

During his presidential campaign, Barack Obama pledged to reverse the course taken by his predecessor along many fronts, including the Bush Administration's posture toward openness in government. Candidate Obama promised to "create a transparent and connected democracy" (Obama 2007). After being sworn in, one of President Obama's first actions was to sign a memorandum committing his administration "to creating an unprecedented level of openness in Government" (Obama 2009a). His administration took numerous steps in its first 100 days to signal a renewed commitment to governmental transparency. 
The Obama Administration's actions provide, even at this early juncture of the new presidency, an excellent opportunity to consider more fully the role of transparency in government - as well as its value as a central part of a governmental reform strategy. At first blush, of course, it might seem as if there would really be little to consider. The electoral repudiation of the Bush Administration's policies, combined with the nearly universal veneration of open government as a political ideal, would make transparency seem the sweet elixir of contemporary governance. The Obama Administration's early rhetoric has only reinforced this widespread veneration of transparency. Since some governmental transparency is good, it might surely seem that greater transparency must always be better still. Yet despite nearly universal acclaim for transparency - or perhaps especially because of it - the concept and its application merits closer examination. Neither scholars nor practitioners know as much about transparency and its effects than might be supposed from the sheer popularity of the concept. What is needed is to know more about the benefits of transparency, as well as its costs. After all, it is possible to have too much of a good thing.

The Bush-to-Obama transition reveals that the most important challenge for open government is not secrecy versus transparency, but figuring out how much transparency, and what type, to have over different aspects of the governmental process. Good, open government is not the same as a reality television show that broadcasts every move officials make and every conversation they have. On the contrary, good government actually requires certain limits on this kind of fishbowl transparency. Moreover, recognition of such limits holds implications for the political 
strategy of open government reform. Reformers who trumpet transparency at nearly every turn, or who suggest that transparency can cure all that ails public policy, raise public expectations of a much too extreme openness. As meeting such high expectations is neither realistic nor wise, raising these expectations poses political risks. The Obama Administration's trumpeting of open government may seem politically appealing in the short term - after all, most Americans support transparency - but in the longer run the new President's rhetoric, and the prominence his administration gives to transparency, risks creating disappointment that may only serve to deepen public cynicism.

\section{Toward Transparency's Triumph}

To a large extent, the prevailing triumph of transparency in the United States grows out of a rejection of both the administrative policies and rhetorical tone of the Bush administration, "one of the most secretive, closed administrations in American history," according to candidate Obama (Obama 2007). The Bush Administration's reputation for secrecy derived in part from its posture over international and homeland security issues. But even before the Bush Administration launched its "global war on terrorism," it staked out a clear position favoring secrecy in certain aspects of domestic policymaking as well. Shortly after assuming office in 2001, for example, President Bush established an energy policy task force, chaired by Vice President Cheney, that met secretly with representatives from the energy industry, raising suspicions of undue influence and even possible violations of the Federal Advisory Committee Act. When 
outside environmental and watchdog groups requested materials from the task force, the White House refused to release the information, prompting the outside groups to file litigation seeking disclosure.

The Bush Administration ultimately prevailed in its position that the White House could keep secret the meetings and deliberations of its energy task force (In re: Richard B. Cheney 2005), but politically, the die had been cast. Throughout its eight years, the Bush Administration sought to expand the power of the Presidency in ways that raised widespread anxieties about an unfettered, unitary executive. These anxieties increased each time the administration sought to keep documents from Congress or the public.

Not long after September 11, 2001, Attorney General John Ashcroft issued a memo encouraging executive branch agencies to think carefully before releasing information under the Freedom of Information Act (FOIA) and offering assurance that the Department of Justice (DOJ) would be inclined to defend agency decisions to withhold documents (Ashcroft 2001). In subsequent years, reports emerged that the White House dictated which agency scientists could speak to the media about climate change, that political appointees from the White House edited agency science reports, and that on at least one occasion the Environmental Protection Agency (EPA) administrator changed his mind over an important regulatory decision due to White House pressure (Committee on Oversight and Government Reform 2007; Committee on Oversight and Government Reform 2008). As these controversies came to light, the 
Bush White House steadfastly resisted Congressional calls to turn over documents detailing its communications with agency officials.

In fairness, it should be noted that some of the positions on executive authority taken by the Bush Administration had been adopted by previous administrations (Calabresi \& Yoo 2008). President William Clinton, for example, took much the same legal position over the release of information about his health care reform task force that the Bush Administration took over its energy policy task force. Moreover, in other ways, the Bush Administration actually took greater strides toward transparency than did previous administrations, such as by making information available online about meetings held between outside groups and the administrator of the White House Office of Information and Regulatory Affairs (OIRA) (Graham 2008). The Bush Administration also invested significant resources and management effort in creating the Internet portal Regulations.Gov, and then in taking steps to use that portal to make available all federal agencies' supporting materials for their new rulemaking proceedings (Coglianese 2007).

Despite efforts such as these, the Bush Administration was widely perceived as having placed a cloak of secrecy over significant aspects of the federal government's operations. Many observers undoubtedly agreed with law professor David Vladeck, who opined that "George W. Bush will go down in the annals of history as 'The Secrecy President'" (Committee on Government Reform Minority Staff 2004).

As a result, toward the end of the Bush Administration it became plain that the next administration - whether Republican or Democratic - would have an opportunity to chart a new course on governmental openness. The major candidates in the 
presidential primary season made transparency and other "good government" issues part of their campaign themes. Professional groups and advocacy organizations also initiated processes to develop transparency-related recommendations for the new administration. These transition projects helped lay a foundation for much of the Obama Administration's open government agenda.

One such project was launched in 2007 by a Washington, D.C.-based transparency advocacy organization called OMB Watch. OMB Watch commissioned an independent task force to focus on transparency and public participation issues in the rulemaking process, and in July 2008 the task force issued a set of twenty-six nonpartisan recommendations. ${ }^{1}$ Among other things, the task force recommended streamlining the processing of Freedom of Information Act (FOIA) requests, encouraging agencies to release agency records proactively using online document repositories, and improving the quality of the federal e-rulemaking portal, Regulations.Gov (Coglianese, Kilmartin \& Mendelson 2009).

Also in 2007, the American Bar Association's (ABA) Section on Administrative Law and the Regulatory Process convened an ad hoc Committee on the Status and Future of Federal e-Rulemaking, chaired by Sally Katzen, President Clinton's OIRA administrator (see ABA 2008). ${ }^{2}$ This committee focused on the progress the Bush Administration had made in developing Regulations.Gov. In an October 2008 report, the committee diagnosed the flaws in Regulations.Gov and offered recommendations that called for a "fundamentally new approach" to both the internal management of the 
federal government's rulemaking data system and public access to that system (Committee on the Status and Future of Federal e-Rulemaking 2008).

Once President Obama won the election in November 2008, still other transparency-related reports and recommendations appeared (Association of Health Care Journalists 2008; Center for Progressive Reform 2008; Liberty and Security Transition Coalition 2009; National Security Archive 2008; OMB Watch 2008a; OMB Watch 2008b; Project on Government Oversight 2008; Sunlight Foundation 2008; Sunshine in Government Initiative 2008). Most of these reports criticized the Ashcroft memo and urged the Obama Administration to take more affirmative responses to FOIA requests, as well as to improve public access by better use of information technology. The sheer number of transparency-related transition reports from diverse organizations lent support to the claim that "government openness is neither a left nor a right issue. It is an American issue" (OMB Watch 2008b).

\section{Transparency's Triumph}

As a candidate, Obama had clearly signaled his support of open government reforms. He spoke out against dangers of special interests and called for an expansion of public access to and participation in governmental decision-making. He decried the Bush Administration's use of "a legal tool known as the 'state secrets' privilege more than any other previous administration to get cases thrown out of civil court" (Obama 2008). Obama promised that, if elected, he would take steps to "make White House 
communications public" and to "conduct regulatory agency business in public" (Obama 2008). He favored the "use [of] cutting-edge technologies to ... creat[e] a new level of transparency, accountability and participation for America's citizens" (Obama 2007). In a pledge his campaign referred to as "Sunlight Before Signing," he even promised to make all "non-emergency bills" available on the White House website for five days before signing them, so the public would have the opportunity to review and comment on them (Obama 2008).

As much as Obama may have surprised the nation by appointing his chief Democratic rival to be Secretary of State, it came as little surprise that transparency became a dominant theme across his Administration's agenda. On his very first full day in office, President Obama signed three presidential memos, one announcing a pay freeze for his senior aides and the other two dealing with open government. The first of these two open government memos declared three abiding values he wanted his Administration to follow: transparency, participation, and collaboration. This memo also ordered the new Director of the Office and Management and Budget (OMB) to issue an "Open Government Directive" specifying concrete steps to implement these values across executive agencies and departments (Obama 2009a). In a potentially bold assertion of executive authority, the memo also stated that "independent agencies should comply with the Open Government Directive" (Obama 2009a).

Obama's second transparency memo directed his Attorney General to develop a new FOIA policy that would clearly establish a presumption in favor of the release of government information. "In the face of doubt," Obama declared, "openness prevails" 
(Obama 2009b). Furthermore, he stated that “the Government should not keep information confidential merely because public officials might be embarrassed by disclosure, because errors and failures might be revealed, or because of speculative or abstract fears" (Obama 2009b). By operating under principles such as these, federal agencies would be able to "usher in a new era of open Government" (Obama 2009b).

In addition to the two open government memos, President Obama issued two open government executive orders on his first day. First, he revoked a Bush executive order that enabled former presidents to limit public access to their official documents. Under the procedures outlined in Obama's new executive order, the National Archives could more easily release these historical records over the objections of a former president (Obama 2009c). Second, Obama issued an executive order imposing ethics requirements on incoming officials and a lobbying ban on officials who leave the administration. Unlike previous presidents who had imposed similar requirements only on their most senior appointees, President Obama imposed his requirements on "every appointee in every executive agency" (Obama 2009d).

A week later, President Obama instructed his OMB director to review a previous executive order issued by President Clinton, and adhered to by President Bush, governing White House review of new regulations. The President called for recommendations for a possible revision of the regulatory review executive order, including suggestions on "disclosure and transparency" (Obama 2009e). Notably, OMB then solicited public comments to help inform its recommendations, a highly unusual, if not unprecedented, step for the development of an executive order (see OMB 2009). By 
the close of the comment period, OMB received over 150 submissions and subsequently posted them on the OMB website. (The office has said that its staff members will read the comments carefully -- although they do not intend to respond to them.)

During the first several weeks of the administration, Obama's economic and legislative teams were preoccupied with brokering a $\$ 787$ billion economic stimulus package - but transparency was nevertheless not forgotten. To monitor spending under the stimulus bill, the legislation created a new Recovery Accountability and Transparency Board. In a speech before a joint session of Congress in February, President Obama announced the creation of a new website - Recovery.gov - intended to ensure "that every American can find out how and where their money is being spent" (Obama 2009f). In mid-March, he issued a presidential memorandum banning conversations between government officials and lobbyists over economic stimulus funds and requiring Internet-based disclosure of written communications (Obama 2009g).

Also in mid-March, Attorney General Eric Holder completed his review of FOIA policy and rescinded the Ashcroft memo. Henceforth, the DOJ would only defend FOIA denials when disclosure was prohibited by law or when an "agency reasonably foresees that disclosure would harm an interest protected by one of the statutory exemptions" from disclosure (Holder 2009). Consistent with recommendations in many of the transition reports, Holder encouraged agencies to consider disclosing records even if technically the records could fit under one of FOIA's exemptions, and urged agencies to 
work "proactively and promptly" to "post information online in advance of any public request" (Holder 2009).

A month later, the Environmental Protection Agency (EPA) issued its own agency-specific transparency guidelines. The new EPA guidelines called for disclosure "wherever possible under the FOIA" and "steps to make information public on the Agency's Web site without waiting for a request from the public to do so" (Jackson 2009). The EPA administrator also announced that her appointment calendar would be posted daily on the agency's website.

In addition to posting government documents and data online, the Obama Administration took steps to use the Internet more interactively. For example, the administration launched the creation of Healthreform.Gov, an interactive site that includes web streaming of health care reform forums, blog postings by government officials, and a comment function that allows the public to share stories and ideas about health care. The President also held an interactive town hall via the Internet, at which he answered questions submitted and voted on by members of the public. Individuals reportedly submitted more than 100,000 questions in advance of the Town Hall, and the online community cast over 3.5 million votes on these questions (Stolberg 2009). Overall, the administration sought to encourage more of these kinds of online innovations through what it has called the Open Government Initiative, a project that, of course, has its own website and blog (Open Government Initiative 2009). The Initiative has publicized new transparency and public participation efforts and solicited public input about the development of additional ones, including using a wiki to allow 
the public to collaborate in the drafting of further transparency-related recommendations.

\section{The Virtues and Vices of Open Government}

The Obama Administration's enthusiastic embrace of transparency fits into a pattern of both broad cultural interest in the Internet and societal support for transparency. Poll data indicate that about $80 \%$ of Americans view making the federal government more open and accountable to be an important priority (Lake Research Partners/Topos Partnership 2009). With nearly everyone agreeing that government should be more transparent, it may seem as if transparency has become viewed as an unalloyed public good, even an end all of its own.

Yet is transparency really the ultimate end that government should strive to serve? Rather than being valued for its own sake, transparency is actually a tool that can advance the much more fundamental goals of good public policy and legitimate governmental decision-making. Transparency can serve these larger ends in both affirmative and preventative ways. First, transparency can affirmatively improve governmental decision-making by helping inform the public about the problems governmental officials seek to solve and the options they are considering. By making more information available, the public can then participate more thoughtfully in the governmental process, sharing new information or raising questions about the adequacy of proposed governmental solutions (Stiglitz 2003). Such informed 
participation by citizens, professional groups, interest organizations, and others can, in turn, help inform governmental officials and enable them to make better decisions.

Second, transparency can help preventatively, making abuses and mistakes by government officials less likely, as those officials know that ordinary citizens, organized interest groups, the media, and other government officials (especially those specifically charged with oversight roles) can more easily monitor the workings of the federal government. When officials know that those outside government can see what they are doing, they are presumably more likely to comply with norms of good governance (Coglianese, Kilmartin \& Mendelson 2009). They may be more careful, less susceptible to expediency or improper influence, and more inclined to try to listen to all concerned. Although transparency can act as a check on bad decision-making and help improve good decision-making, this does not mean that greater transparency is always better. Too much transparency - or transparency in the wrong places - might actually detract from officials' ability to make good decisions. One worry is that under an extreme transparency achievable today with the aid of advanced technology, officials will not engage in as probing and self-critical forms of deliberation because they know that outsiders could be monitoring everything they say and do -- and perhaps will try to use against them later what they say when simply "thinking aloud." Although transparency may help inhibit undesirable forms of behavior, total transparency is also likely to inhibit other, desirable behavior - such as internal dissent or asking the proverbial dumb question - that might be embarrassing but is still necessary for good decision-making (Sunstein 2003). 
Total transparency could also make it less likely that government officials would gain useful information from private actors (Coglianese, Zeckhauser \& Parson 2004).

Certain kinds of trade secrets or other sensitive business information may be essential for government officials to obtain and analyze in order to adopt effective policies regulating industry. Clearly, businesses would be even more reluctant to share such information with government if they knew it would not only help regulators but also need to be disclosed to competitors and to the public.

Recognizing that some circumstances or types of information call for confidentiality and secrecy, even officials in the Obama Administration accept that "the disclosure obligation ... is not absolute" (Holder 2009). The question is not transparency or secrecy, but how much transparency to foster -- and about what types of information to disclose. FOIA itself exempts from disclosure documents involving national security issues, personnel matters, or trade secrets. Attorney General Holder's memo on FOIA indicates that the DOJ will defend agency decisions to withhold records not merely when they fall under these exemptions in the law, but also when releasing the records simply "would harm an interest protected by one of the statutory exemptions" (Holder 2009, emphasis added). Despite President Obama's seemingly absolutist rhetoric about a "new era of open government," he surely realizes that governing well requires making tradeoffs.

Less clearly acknowledged, though, is the question of exactly what kind of transparency to promote. The Obama Administration, as well as most of the organized groups and tech-savvy individuals that advocate open government, have emphasized 
what could be called fishbowl transparency. The aim is to expand the release of information that can document how government officials actually behave, such as by disclosing meetings held between White House staff and outside groups. But there is another type of transparency, reasoned transparency, that demands that government officials offer explicit explanations for their actions. Sound explanations will be based on application of normative principles to the facts and evidence accumulated by decision-makers - and will show why other alternative courses of action were rejected. Sound policy explanations are not the same as the kind of account that journalists or social scientists would give if they were trying to explain, as an empirical matter, why a policy was in fact adopted, an account that would clearly be aided by an expansion of fishbowl transparency. Instead, reasoned transparency depends on making a substantive evaluation of the soundness of an official's reasoning, not on knowing whether that official might have met with one interest group or another.

This distinction in types of transparency is important because whenever limits need to be placed on fishbowl transparency, whether to preserve space for robust deliberation or to advance other values such as national security or personal privacy, reasoned transparency can still discipline governmental decision-making - serving the same goals as fishbowl transparency -- if officials know they must provide sound reasons for their decisions. Unfortunately, the current fascination with the Internet appears to make it easy to lose sight of the value of reasoned transparency. The U.S. governmental process may well benefit even more from an improvement in reasoned transparency than from the vast expansion of fishbowl transparency that modern 
technology would now permit. Modern information technology may give us more noise, when what we really need is better music.

Developing open government policies is more complex than any bumper-sticker rhetoric would imply. Greater transparency - of the fishbowl variety - is not always better. In developing federal open government rules, decision-makers need to balance both the advantages and disadvantages of expanded transparency, and to consider which type of transparency (if any) ought to be expanded. Addressing these issues demands a better understanding than we currently have of how different types of, and different levels of, transparency affect governmental behavior, policy outcomes, and public perceptions of legitimacy.

Despite politicians and the public's fervor for transparency, social scientists have had much too little to say about how government officials and the public respond under different levels and types of transparency. Will greater transparency, of one kind or another, deliver more benefits than costs? This is a hard question for empirical research to address for several reasons. For one, the variable we care most about understanding - transparency -- is hard to measure. What exactly does a unit of transparency look like? In addition, the outcomes that transparency presumably affects - decisional quality and legitimacy -- are also exceedingly difficult to measure, and many factors other than transparency come into play in affecting these outcomes.

Despite these difficulties, designers of open government standards - that is, legislators, agency administrators, and government lawyers -- surely could demand more of the research community instead of simply relying on the assumption that 
greater transparency is always better. It may turn out to be the case, for example, that there are diminishing marginal returns to transparency. That is to say, when a highly secretive government makes a shift from virtually no transparency to even a modest level of transparency, the behavioral effects in terms of good governance may be much more dramatic than when an already quite open government shifts to a still higher level of transparency.

The possibility of diminishing returns is worth contemplating because, at least compared to other countries, the federal government in the United States already has quite an open public policy process -- both in terms of fishbowl and reasoned transparency. Statutes such as the FOIA, Administrative Procedure Act (APA), and Government in Sunshine Act have long compelled government offices to make information available to the public and to give the public opportunities to comment on proposed policies. Even during the Bush years, the administration's critics learned much about governmental actions, not only from document "leaks" by sympathetic insiders (Roberts 2008) but also from filing FOIA requests (Kreimer 2007; Kreimer 2008). In addition to laws like FOIA which enhance fishbowl transparency, long-established practices of legislative and judicial oversight have reinforced reasoned transparency. When cabinet secretaries and agency administrators must testify before a congressional committee or respond to lawsuits filed under the APA's "arbitrary and capricious" standard, they must provide and defend their reasons.

Even against the existing baseline, of course, the U.S. system can always be made more transparent. Governmental reasoning could often be much stronger, and the 
fishbowl could be more translucent. But it will always be possible to say things could be more transparent in the fishbowl sense, at least until cameras and microphones are placed in every government office, or chips loaded in the brains of bureaucrats, with the digital data instantly uploaded to the Internet. Although greater visibility may always be possible, it may not always be needed or justified. Additional incremental increases in transparency should occur only when they will have, on balance, a positive effect on the quality or legitimacy of government decisions.

\section{The Political Economy of Transparency}

Whatever the underlying virtues and vices of enhancing still further the transparency of the U.S. federal government, it is not hard to see why, as a matter of political strategy, President Obama would want to make open government such a major theme at the start of his administration. For one thing, he presumably genuinely believes that the federal government should be more transparent. But the political economy of transparency also makes it easier for him to act on this conviction. Advocating transparency not only distances his administration from his unpopular predecessor's, but transparency sells well. Everyone seems to favor it, whether on the political left or the right. The beneficiaries of enhanced transparency are well-organized groups of all stripes; businesses favor transparency as much as public interest groups do. Any potential losers from a new presumption of openness are generally unknown and unorganized - since they lose only when specific information is disclosed at some 
point in the future. Furthermore, making government information more readily available to the public requires little in the way of additional budgetary resources, and the President can announce and act on his commitment to transparency without needing congressional approval (though he would likely receive it anyway). In the short-term, then, it seems clear that President Obama had little reason politically not to declare he would usher in a "new era of open government."

In the medium to long term, though, the political calculus does not work out so clearly in Obama's strategic favor. Having emphasized transparency at nearly every turn, the President has now raised public expectations that are likely to be difficult to meet over the duration of his administration. Every time he or his cabinet resists the disclosure of government records, he risks disappointing the left and making himself vulnerable to charges of hypocrisy by the right.

In just his first few months in office, President Obama has already had to make decisions that compromise complete transparency -- and afterwards he has consistently found himself subject to criticism. For example, despite candidate Obama's statements opposing the Bush Administration's use of the "state secrets" privilege, DOJ attorneys serving under President Obama have continued (sometimes unsuccessfully) to invoke this privilege in litigation (Binyam v. Dataplan 2009). According to one commentator, the Obama DOJ's position on the state secrets privilege "is equal to, and in some senses surpasses, the radical secrecy and immunity claims of the Bush administration" (Greenwald 2009). 
Criticisms have also been leveled at the Obama Administration when it has denied FOIA requests, however legal and appropriate such denials may have been. The most salient such case involved a request by the American Civil Liberties Union (ACLU) for the release of photos documenting military personnel's treatment of detainees. After initially indicating he would support the release of these photos, President Obama reversed course and decided to deny the ACLU's FOIA request, stating that the photos' release would endanger American troops. As one of many news accounts reported, "civil liberties and human rights advocates said the [President's] reversal would serve to maintain the Bush administration's legacy of secrecy" (Wilson 2009). The ACLU attorney seeking the photos declared, not surprisingly, that "this essentially renders meaningless President Obama's pledge of transparency and accountability that he made in the early days after taking office" (Wilson 2009).

Similar concerns about Obama's ability to deliver on his promises have surfaced in connection with the Recovery.Gov website, which the president declared would enable the public to track the spending of federal dollars appropriated by the economic stimulus legislation. The Washington Post has reported that "three months after the bill was signed, Recovery.gov offers little beyond news releases, general breakdowns of spending, and acronym-laden spreadsheets and timelines. And congressional Democrats, state officials and advocates of open government worry that the White House cannot come close to clearing the high bar it set" (MacGillis 2009).

Candidate Obama's "Sunlight Before Signing" pledge may have set yet another unrealistically high bar, as it has been a regular source of fodder for the president's 
critics. Only about one out of the first dozen pieces of legislation signed by the president had been posted on the White House website for the promised five-day period of public comment (Harper 2009). With each piece of legislation's approval in the absence of the public comment period, the President has provided an opportunity for critics and the media to remind the public about his (unmet) campaign pledge (Henry 2009).

\section{Conclusion}

As a matter of political strategy, then, transparency is a double-edged sword. During the transition from the Bush Administration, it may well have looked like trumpeting the cause of open government would be an easy way for any new president to score political points, especially when taking over from a reviled predecessor with a reputation for secrecy. But President Obama's rhetoric and zeal for transparency has also created false impressions - and unrealistic expectations -- about what it takes to make open government work well. Just as good governance requires making judgment calls and difficult tradeoffs about other policy criteria, good open governance requires the same about transparency.

To be sure, the Obama Administration is already making transparency tradeoffs. Rhetorical speeches and new websites notwithstanding, this administration appears no less prone than previous ones to protecting the opacity of internal government deliberations and to placing limits on information disclosure when officials believe doing so would serve important policy objectives. But this reality only underscores the 
political risk of giving transparency such prominence on a new president's reform agenda. Members of the general public, and certainly of the open government activist community, may not appreciate the full complexities of governing nor be willing to support anything less than full disclosure. Given the political risks created by

heightened expectations, it remains to be seen whether Barack Obama will end his time in office having secured a reputation as the "transparency president" - or whether Americans' recently raised hopes for renewed openness in government will only turn back to renewed cynicism about government.

\section{Acknowledgements}

An earlier version of this paper was delivered as a keynote address at the American Bar Association's 5th Annual Administrative Law and Regulatory Practice Institute, Washington, D.C., June 2009. The author is grateful for helpful comments from Anna Gavin, Bill Luneburg, Alasdair Roberts, and Albert Schilthuis. A revised version of this paper is forthcoming in Governance.

\section{Notes}

1. The author served as the chair of this task force and selected its members.

2. The author served as a member of this committee. 


\section{References}

American Bar Association (ABA) Section on Administrative Law and Regulatory Practice. 2008. Improving the Administrative Process: A Report to the President-Elect of the United States. Washington, DC: American Bar Association Section on Administrative Law and Regulatory Practice. Available at http:/ / www.abanet.org/adminlaw/Report\%20to\%20the\%20PresidentElect $\% 20$ Oct $\% 202008 \%$ 20Final.pdf

Ashcroft, John. 2001. Memorandum for Heads of All Federal Departments and Agencies: The Freedom of Information Act, Oct. 12.

Association of Health Care Journalists. 2009. Letter to President Barack Obama, Feb. 26. Available at http:/ / www.healthjournalism.org/ uploads/AHCJ-letter-to-Obamatransparency.pdf.

Binyam v. Dataplan, Inc. 2009. United States Court of Appeals for the Ninth Circuit. No. 08-15693, April 28.

Calabresi, Steven G. and Christopher S. Yoo. 2008. The Unitary Executive: Presidential Power from Washington to Bush. New Haven, Conn.: Yale University Press.

Center for Progressive Reform. 2008. Protecting Public Health and the Environment by the Stroke of a Presidential Pen: Seven Executive Orders for the President's First 100 Days. Available at http:/ / www.progressivereform.org/penstroke.cfm

Coglianese, Cary. 2007. “Weak Democracy, Strong Information: The Role of Information Technology in the Rulemaking Process." In From Electronic Government to Information Government: Governing in the 21st Century, eds. Viktor MayerSchoenberger \& David Lazer. Cambridge, Mass.: MIT Press.

Coglianese, Cary, Heather Kilmartin, and Evan Mendelson. 2009. “Transparency and Public Participation in the Federal Rulemaking Process: Recommendations for the New Administration." George Washington Law Review 77:101.

Coglianese, Cary, Richard Zeckhauser, and Edward Parson. 2004. "Seeking Truth for Power: Informational Strategy and Regulatory Policy Making." Minnesota Law Review 89: 277-341.

Committee on Government Reform Minority Staff. 2004. Secrecy in the Bush Administration, Sept. 14. Washington, D.C.: U.S. House of Representatives.

Committee on Oversight and Government Reform. 2007. Political Interference with Climate Change Science under the Bush Administration. Washington, D.C.: U.S. House of Representatives. 
-------. 2008. Memorandum: EPA's Denial of the California Waiver. May 19.

Committee on the Status and Future of Federal e-Rulemaking. 2008. Achieving the Potential: The Future of Federal e-Rulemaking. Washington, DC: American Bar Association Section on Administrative Law and Regulatory Practice.

Graham, John D. 2008. Saving Lives through Administrative Law and Economics. University of Pennsylvania Law Review 157: 395.

Greenwald, Glenn. 2009. “New and Worse Secrecy and Immunity Claims from the Obama DOJ." Salon.Com, April 6. Available at http://archive.salon.com/opinion/greenwald/2009/04/06/obama/index.html

Harper, Jim. 2009. “The Promise that Keeps on Breaking." Cato Institute, April 13. Available at http://www.cato.org/tech/tk/090413-tk.html

Henry, Ed. 2009. “Obama Signing Friday Breaks Transparency Pledge.” CNNPolitics.com, May 20. Available at http:/ / politicalticker.blogs.cnn.com/2009/05/20/obama-signing-friday-breakstransparency-pledge/

Holder, Eric. 2009. Memorandum for Heads of Executive Departments and Agencies: The Freedom of Information Act. Mar. 19.

In re: Richard B. Cheney. 2005. Federal Reporter 406: 723, Washington, D.C.: United States Court of Appeals for the District of Columbia Circuit.

Jackson, Lisa P. 2009. Memorandum: Transparency in EPA's Operations, Apr. 23. Available at http:/ / www.epa.gov/administrator/operationsmemo.html

Kreimer, Seth. 2007. "Rays of Sunlight in a Shadow 'War': Subconstitutional Structures of Transparency and Antiterrorist Abuses." Lewis \& Clark Law Review 11:1141.

-------. 2008. "The Freedom of Information Act and the Ecology of Transparency." University of Pennsylvania Journal of Constitutional Law 10: 1011.

Lake Research Partners/Topos Partnership. 2009. Transparency Poll Data Memo. Available at http://www.pogo.org/pogo-files/alerts/economic-recovery/er-s20090204.html

Liberty and Security Transition Coalition. 2009. Liberty and Security: Recommendations for the Next Administration and Congress. Available at http:/ / 2009transition.org/libertysecurity $/$ index.php?option=com_content\&view=article\&id=11\&Itemid=21 
MacGillis, Alec. 2009. "Tracking Stimulus Spending May Not Be as Easy as Promised." Washington Post, May 21. Available at http://www.washingtonpost.com/wpdyn/content/article/2009/05/20/AR2009052003535.html

National Security Archive. 2008. Memorandum to Transition Team: The Freedom of Information Act. Available at http://www.gwu.edu/ nsarchiv/nsa/foiatrans/FOIA_Transition_Recommend ation.pdf

Obama, Barack. 2007. "Connecting and Empowering All Americans Through Technology and Innovation." Available at http://cairns.typepad.com/blog/files/fact_sheet_innovation_and_technology_p lan_final.pdf

2008. "Blueprint for Change: Obama and Biden's Plan for America." Available at http://www.barackobama.com/pdf/ObamaBlueprintForChange.pdf

-. 2009a. "Memorandum for the Heads of Executive Departments and Agencies: Transparency and Open Government." Jan. 21. Available at http://www.whitehouse.gov/the_press_office/Freedom_of_Information_Act/

--. 2009b. "Memorandum for the Heads of Executive Departments and Agencies: Freedom of Information Act." Jan. 21. Available at http://www.whitehouse.gov/the_press_office/Transparency_and_Open_Gover nment/

2009c. "Executive Order - Presidential Records." Jan. 21. Available at http://www.whitehouse.gov/the_press_office/Presidential_Records/

--------. 2009d. “Executive Order - Ethics Commitments by Executive Branch Personnel." Jan. 21. Available at http://www.whitehouse.gov/the_press_office/Ethics-Commitments-ByExecutive-Branch-Personnel/

2009e. "Memorandum for the Heads of Executive Departments and Agencies: Regulatory Review." Jan. 30. Available at http://www.whitehouse.gov/the_press_office/Presidential-MemorandumRegarding-Regulatory-Review/

----- 2009f. "Remarks of President Barack Obama - Address to Joint Session of Congress." Available at http://www.whitehouse.gov/the_press_office/Remarksof-President-Barack-Obama-Address-to-Joint-Session-of-Congress/

2009g. "Memorandum for the Heads of Executive Departments and Agencies: Ensuring Responsible Spending of Recovery Act Funds." Mar. 20. Available at 
http:/ / www.whitehouse.gov/the_press_office/Memorandum-for-the-Heads-ofExecutive-Departments-and-Agencies-3-20-09/

Office of Management and Budget (OMB). 2009. "Federal Regulatory Review: Request for Comments." Federal Register (Feb. 26) 74: 8819.

OMB Watch. 2008a. Advancing the Public Interest through Regulatory Reform. Nov. Washington, D.C.: OMB Watch.

-------. 2008b. Moving Toward a 21st Century Right-To-Know Agenda:

Recommendations to President-elect Obama and Congress. Nov. Washington, D.C.: OMB Watch.

Open Government Initiative. 2009. Available at http://www.whitehouse.gov/open/

Project on Government Oversight. 2008. Recommendations for Transition Teams. Available at http:/ / pogoarchives.org/m/go/transition-paper-20081016.pdf

Roberts, Alasdair. 2008. The Collapse of Fortress Bush: The Crisis of Authority in American Government. New York: New York University Press.

Stiglitz, Joseph E. 2003. “On Liberty, the Right to Know, and Public Discourse: The Role of Transparency in Public Life." In Globalizing Rights: The Oxford Amnesty Lectures 1999, ed. Matthew Gibney. Oxford: Oxford University Press.

Stolberg, Sheryl Gay. 2009. "Obama's Interactive Town Hall Meeting." The Caucus: The Politics and Government Blog of the Times. Mar. 26. Available at http:/ / thecaucus.blogs.nytimes.com/2009/03/26/obamas-interactive-townhall-meeting/?ref=politics

Sunlight Foundation. 2008. Open Letter to the Obama Administration on How to Shine Sunlight. Nov. 6. Available at http:/ / blog.sunlightfoundation.com/2008/11/06/open-letter-to-the-obamaadministration-on-how-to-shine-sunlight/

Sunshine in Government Initiative. 2008. Media Coalition Recommendations for Action by the Obama Administration to Strengthen Transparency and Integrity in Government. Nov.

Sunstein, Cass R. 2003. Why Societies Need Dissent. Cambridge, MA: Harvard University Press.

Wilson, Scott. 2009. “Obama Shifts on Abuse Photos.” Washington Post, May 14. Available at http:/ / www.washingtonpost.com/wpdyn/content/article/2009/05/13/AR2009051301751.html?sid=ST2009051303180 